\title{
Synthesis and Antimicrobial Activities of $N^{\prime}$-[(2-Chloro-6-methoxy quinolin-3-yl)methylidene]- substituted Benzohydrazide
}

\author{
SAMIR S. SHAIKH
}

Department of Chemistry, Gramonnati Mandal's Arts, Comm. \& Sci. College, Affiliated to University of Pune, Narayangaon-410504, Pune, Maharashtra, India ss.samir@rediffmail.com

Received 18 December 2012 / Revised 26 January 2013 / Accepted 17 February 2013

\begin{abstract}
A number of $N^{\prime}$-[(2-chloro-6-methoxyquinolin-3-yl) methylidene]-substituted benzohydrazide have been synthesized by the treatment of 2-chloro-6-methoxy-3-quinolinecarbaldehyde with the substituted benzohydrazides. The structures of the synthesized compounds have been characterized by using IR and ${ }^{1} \mathrm{H}$ NMR spectroscopy. These compounds were screened for their antibacterial as well as antifungal activity. Compounds show grater antibacterial activity as compare to antifungal activity.
\end{abstract}

Keywords: 2-Chloro-6-methoxy-3-quinolinecarbaldehyde, Benzohydrazides, Antimicrobial activities

\section{Introduction}

Hydrazide analogues having azomethine $(-\mathrm{CONHN}=\mathrm{CH}-)$ group show antimicrobial activities and it also possess other biological activities like anticonvulsant, antidepressant, analgesic $^{1,2}$, anti-inflammatory ${ }^{3}$, antimalarial, anticancer activities. It is also active against experimental tuberculosis in guinea pigs ${ }^{4,5}$. In in-vitro metabolism studies, it has been found that hydrazide-hydrazones undergo hydrolytic reactions and aromatic rings undergo aromatic hydroxylation reactions and give positive effect for cure of diseases ${ }^{6,7}$. GökhanKelekçi et al. synthesized hydrazones containing 5-methyl-2-benzoxazoline ${ }^{8}$. The analgesic effects of 2-[2-(5-methyl-2-benzoxazoline-3-yl) acetyl]-4-chloro- /4-methyl benzylidene hydrazine were found to be higher than those of morphine and aspirin ${ }^{8}$. Hydrazide-hydrazones compounds are not only intermediates but they are also very effective organic compounds in their own right. When they are used as intermediates, coupling products can be synthesized by using the active hydrogen component of $\mathrm{CONHN}=\mathrm{CH}$ - azomethine group 9 . In continuation of this work to develop potential antimicrobial molecules ${ }^{10}$, we report here the synthesis of some derivatives by combining two biological active compounds (3-formyl 2-chloro quinolines and substituted benzohydrazides) having azomethine group and characterized by spectral data with evaluation for their antimicrobial activity. 


\section{Experimental}

All the reagents were obtained commercially and used with further purification. The melting points were determined on microprocessor MP apparatus, IR spectra were recorded with a FTIR spectrometer in KBr optics. ${ }^{1} \mathrm{H}$ NMR spectra were recorded on a DPX-300 MHz spectrometer in DMSO-d6 solutions. The chemical shifts were expressed in the ppm $(\delta$ scale) downfield from TMS. For purification of prepared compounds column chromatography was used as per requirement. Thin layer chromatography (TLC) was performed to check the purity of the compounds, spots being visualized under UV cabinet.

\section{General procedure for the preparation of benzohydrazides (2a-2e)}

The esterification of the substituted benzoic acids was performed by reported method ${ }^{11}$. It was carried out by refluxing acids $(0.246 \mathrm{~mol})$ with methanol in sulpuric acid for $4 \mathrm{~h}$. Then esters were separated out and converted into benzoic acid hydrazides or benzohydrazides by hydrazinolysis process ${ }^{11}$ (Scheme 1).

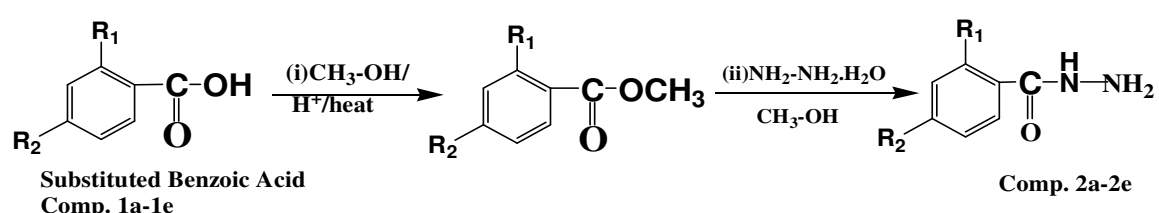

1a: $\mathrm{R}_{1}=\mathrm{R}_{2}=\mathrm{H}, 1 \mathrm{~b}: \mathrm{R}_{1}=\mathrm{H} ; \mathrm{R}_{2}=\mathrm{CH}_{3}$, 1c: $\mathrm{R}_{1}=\mathrm{H} ; \mathrm{R}_{2}=\mathrm{OCH}_{3}$, Id: $\mathrm{R}_{1}=\mathrm{H} ; \mathrm{R}_{2}=\mathrm{CI} ; 1 \mathrm{e}: \mathrm{R}_{1}=\mathrm{R}_{2}=\mathrm{CI}$

2a: $\mathrm{R}_{1}=\mathrm{R}_{2}=\mathrm{H} ; 2 \mathrm{~b}: \mathrm{R}_{1}=\mathrm{H} ; \mathrm{R}_{2}=\mathrm{CH}_{3}, 2 \mathrm{c}: \mathrm{R} 1=\mathrm{H} ; \mathrm{R}_{2}=\mathrm{OCH}_{3}, 2 \mathrm{~d}: \mathrm{R}_{1}=\mathrm{H} ; \mathrm{R}_{2}=\mathrm{CI} ; 2 \mathrm{e}: \mathrm{R}_{1}=\mathrm{R}_{2}=\mathrm{CI}$

Scheme 1. Synthesis of benzohydrazides from substituted benzoic acid

\section{General procedure for the synthesis of 2-chloro-6-methoxy-3-quinoline} carbaldehyde (4)

These compounds were prepared by modified reported $\operatorname{method}^{12} . N, N$-Dimethylformamide $(9.1 \mathrm{~g}$, $9.6 \mathrm{~mL}$ and $0.125 \mathrm{~mol}$ ) was cooled to $0{ }^{\circ} \mathrm{C}$ and phosphoryl chloride $(53.7 \mathrm{~g}, 32.2 \mathrm{~mL}, 0.35 \mathrm{~mol})$ was added drop wise with stirring. To this solution 4-methoxy acetanilide $(0.05 \mathrm{~mol})(3)$ was added and the temperature of the reaction mixture was raised to $80{ }^{\circ} \mathrm{C}$ for $18 \mathrm{~h}$. The cooled reaction mixture was poured into ice water $(300 \mathrm{~mL})$ and stirred for $1 \mathrm{~h}$ at $0-10{ }^{0} \mathrm{C}$. The precipitated 2-chloro-3-quinolinecarbaldehyde was filtered off, dried, and recrystallized from ethyl acetate to give the 2-chloro-6-methoxy-3-quinoline carbaldehyde (4) product $^{12,13}$ (Scheme 2).

Yield: 49\%, mp. $143-144{ }^{0} \mathrm{C}$; IR (KBr) cm$\left.{ }^{-1}: 1693(\mathrm{C}=\mathrm{O}), 1619(\mathrm{C}=\mathrm{C}), 1595 \mathrm{C}=\mathrm{N}\right)$, 751 (C-Cl). ${ }^{1} \mathrm{H}$ NMR (300MHz, DMSO-d6, $\delta$, ppm): 10.50 (s, 1H, CHO), 8.57 (s, 1H, H-4), $7.91(\mathrm{~d}, 1 \mathrm{H}, \mathrm{J} 1 / 49.0 \mathrm{~Hz}, \mathrm{H}-8) ; 7.46(\mathrm{dd}, 1 \mathrm{H}, \mathrm{J} 1 / 49.0 \mathrm{~Hz}$ and $2.8 \mathrm{~Hz}, \mathrm{H}-7), 7.17$ (d, 1H, J 1/4 $2.8 \mathrm{~Hz}, \mathrm{H}-5$ ), 3.94 (s, 3H, OCH3); Mol. formula $\mathrm{C}_{11} \mathrm{H}_{8} \mathrm{C}_{1 \mathrm{NO}_{2}}$.Calcd. Mol.wt. 221.02.

General procedure for the synthesis of $N^{\prime}$-[(2-chloro-6-methoxyquinolin-3-yl) methyllidene]benzohydrazide (5a-5e)

Benzohydrazides $(0.01 \mathrm{~mol}), 2$-chloro-6-methoxy-3-quinolinecarbaldehyde $(0.01 \mathrm{~mol})$ were taken in ethanol with catalytic amount of acetic acid $(20 \mathrm{~mL})$ and heated to refluxed for 3-4 $\mathrm{h}$. After completion of the reaction (reaction monitored by TLC method), the reaction mixture was poured into crushed ice. The solid mass thus separated out was filtered, washed with water and dried to give the desired compounds with good yields. IR and ${ }^{1} \mathrm{H}$ NMR analysis were performed for the compounds (Scheme 3 ). 


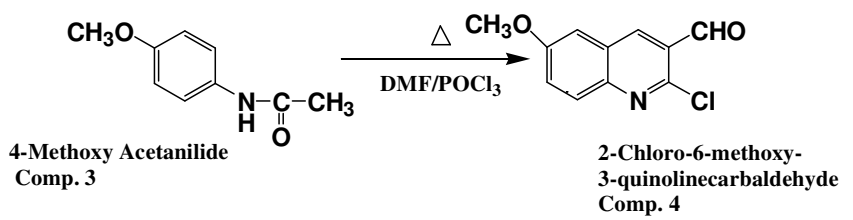

Scheme 2. Synthesis of 2-chloro-6-methoxy-3-quinolinecarbaldehyde

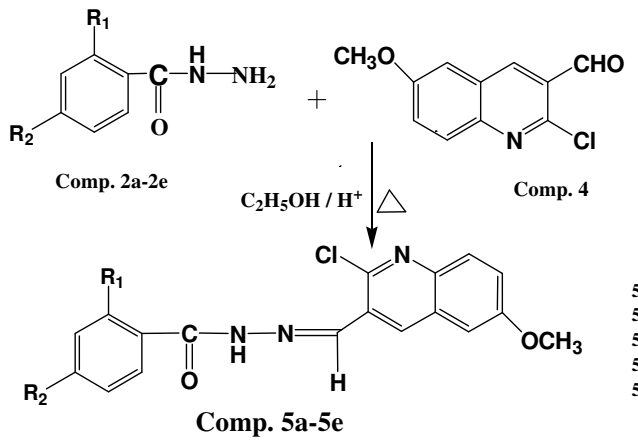

Scheme 3. Synthesis of $N^{\prime}$-[(2-chloro-6-methoxyquinolin-3yl)methylidene ]benzohydrazides

$N^{\prime}$-[(2-Chloro-6-methoxyquinolin-3-yl)methylidene]benzohydrazide (5a)

Yield: $71 \%$, M.P. $183{ }^{\circ} \mathrm{C}$. IR (KBr) cm ${ }^{-1}$ : $3261(\mathrm{~N}-\mathrm{H}), 1655(\mathrm{C}=\mathrm{O}), 1627(\mathrm{C}=\mathrm{N}), 1589$ $(\mathrm{C}=\mathrm{C}), 759(\mathrm{C}-\mathrm{Cl}) .{ }^{1} \mathrm{H}$ NMR $\left(300 \mathrm{MHz}, \mathrm{DMSO}-d_{6}\right): \delta 3.89\left(\mathrm{~s}, 3 \mathrm{H}, \mathrm{OCH}_{3}\right), 7.57-7.64$ (m, 3H, H-3', 4' and 5'), 7.67-7.73 (d, 1H, H-7, $J=8.49 \mathrm{~Hz}), 7.68-7.88(\mathrm{~d}, 1 \mathrm{H}, \mathrm{H}-8, J=8.52$ $\mathrm{Hz}), 7.79-8.01$ (m, 3H, H-2', 6'and 5), 8.81 (s, 1H, H-4), $8.93(\mathrm{~s}, 1 \mathrm{H}, \mathrm{CH}=\mathrm{N}), 12.26(\mathrm{~s}, 1 \mathrm{H}$, CONH). Mol.formula $\mathrm{C}_{18} \mathrm{H}_{14} \mathrm{ClN}_{3} \mathrm{O}_{2}$ Calcd.Mol.wt. 339.75.

$N^{\prime}$-[(2-Chloro-6-methoxyquinolin-3-yl)methylidene]-4-ethylbenzohydrazide (5b)

Yield: 65\%, M.P. $173{ }^{\circ} \mathrm{C}$. IR (KBr) cm ${ }^{-1}: 3223(\mathrm{~N}-\mathrm{H}), 1668(\mathrm{C}=\mathrm{O}), 1622(\mathrm{C}=\mathrm{N}), 1597$ $(\mathrm{C}=\mathrm{C}), 751(\mathrm{C}-\mathrm{Cl}) .{ }^{1} \mathrm{H}$ NMR $\left(300 \mathrm{MHz}, \mathrm{DMSO}-d_{6}\right): \delta 3.84\left(\mathrm{~s}, 3 \mathrm{H}, \mathrm{OCH}_{3}\right), 2.52\left(\mathrm{~s}, 3 \mathrm{H}, \mathrm{CH}_{3}\right)$, 7.35-7.38 (d, 2H, H-3' and 5', $J=7.68 \mathrm{~Hz}), 7.66-7.72(\mathrm{~d}, 1 \mathrm{H}, \mathrm{H}-7, J=8.43 \mathrm{~Hz}), 7.83-7.89$ (d, 3H, H- 2', 6' and 8, J = $8.07 \mathrm{~Hz}), 7.78(\mathrm{~s}, 1 \mathrm{H}, \mathrm{H}-5), 8.84(\mathrm{~s}, 1 \mathrm{H}, \mathrm{H}-4), 8.91(\mathrm{~s}, 1 \mathrm{H}$, $\mathrm{CH}=\mathrm{N}), 12.19$ (s, 1H, CONH). Mol.formula $\mathrm{C}_{19} \mathrm{H}_{16} \mathrm{ClN}_{3} \mathrm{O}_{2}$ Calcd.Mol.wt. 353.78.

$N^{\prime}$-[(2-Chloro-6-methoxyquinolin-3-yl)methylidene]-4-methoxybenzohydrazide (5c)

Yield: 62\%, M.P.183-186 ${ }^{\circ}$ C. IR (KBr) cm ${ }^{-1}: 3223(\mathrm{~N}-\mathrm{H}), 1673(\mathrm{C}=\mathrm{O}), 1629(\mathrm{C}=\mathrm{N}), 1588$ $(\mathrm{C}=\mathrm{C}), 761(\mathrm{C}-\mathrm{Cl}) .{ }^{1} \mathrm{H}$ NMR $\left(300 \mathrm{MHz}, \mathrm{DMSO}-d_{6}\right) ; \delta 3.89\left(\mathrm{~s}, 3 \mathrm{H}, \mathrm{OCH}_{3}\right), 3.82(\mathrm{~s}, 3 \mathrm{H}$, $\left.\mathrm{OCH}_{3}\right), 7.31-7.34\left(\mathrm{~d}, 2 \mathrm{H}, \mathrm{H}-3^{\prime}\right.$ and $\left.5^{\prime}, J=7.72 \mathrm{~Hz}\right), 7.69-7.72(\mathrm{~d}, 1 \mathrm{H}, \mathrm{H}-7, J=8.51 \mathrm{~Hz})$, 7.85-7.88 (d, 1H, H-8, J = 8.42 Hz), 7.77-8.02 (m, 3H, H-2', 6' and 5), 8.82 (s, 1H, H-4), $8.92(\mathrm{~s}, 1 \mathrm{H}, \mathrm{CH}=\mathrm{N}), 12.17(\mathrm{~s}, 1 \mathrm{H}, \mathrm{CONH})$. Mol. formula $\mathrm{C}_{19} \mathrm{H}_{16} \mathrm{ClN}_{3} \mathrm{O}_{3}$ Calcd.Mol.wt. 369.78.

\section{4-Chloro- $N^{\prime}-[(2-$ chloro-6-methoxyquinolin-3-yl)methylidene $]$ benzohydrazide $(\mathbf{5 d})$}

Yield: 67\%, M.P.211-214 ${ }^{\circ} \mathrm{C}$. IR (KBr) cm ${ }^{-1}: 3264(\mathrm{~N}-\mathrm{H}), 1683(\mathrm{C}=\mathrm{O}), 1630(\mathrm{C}=\mathrm{N}), 1589$ $(\mathrm{C}=\mathrm{C}), 757(\mathrm{C}-\mathrm{Cl}) .{ }^{1} \mathrm{H}$ NMR $\left(300 \mathrm{MHz}, \mathrm{DMSO}-d_{6}\right): \delta 3.92\left(\mathrm{~s}, 3 \mathrm{H}, \mathrm{OCH}_{3}\right), 7.63-7.65(\mathrm{~d}, 2 \mathrm{H}, \mathrm{H}-$ $3^{\prime}$ and $\left.5^{\prime} J=8.38 \mathrm{~Hz}\right), 7.56-7.72(\mathrm{~d}, 1 \mathrm{H}, \mathrm{H}-7, J=8.56 \mathrm{~Hz}), 7.82-7.88(\mathrm{~d}, 1 \mathrm{H}, \mathrm{H}-8, J=8.59 \mathrm{~Hz})$, 7.98-8.01 (m, 3H, H-2', 6' and 5), 8.82(s, 1H, H-4), 8.91 (s, 1H, CH=N), 12.25 (s, 1H, CONH). Mol.formula $\mathrm{C}_{18} \mathrm{H}_{13} \mathrm{Cl}_{2} \mathrm{~N}_{3} \mathrm{O}_{2}$ Calcd.Mol.wt. 374.20. 


\section{2,4-Dichloro-N'-[(2-chloro-6-methoxyquinolin-3-yl)methylidene]benzohydrazide (5e)}

Yield: 56\%, M.P.233-237 ${ }^{\circ}$ C. IR (KBr) cm ${ }^{-1}: 3220(\mathrm{~N}-\mathrm{H}), 1672(\mathrm{C}=\mathrm{O}), 1629(\mathrm{C}=\mathrm{N}), 1582$ $(\mathrm{C}=\mathrm{C}), 763(\mathrm{C}-\mathrm{Cl}) .{ }^{1} \mathrm{H}$ NMR $\left(300 \mathrm{MHz}, \mathrm{DMSO}-d_{6}\right) ; \delta 3.93\left(\mathrm{~s}, 3 \mathrm{H}, \mathrm{OCH}_{3}\right), 7.53-7.72(\mathrm{~m}$, $3 \mathrm{H}-3$ ' and 5', 7), 7.86-7.89 (m, 2H, H- 6' and 8), 7.79 (s, 1H, H-5), 8.82 (s, 1H, H-4), 8.94 (s, $1 \mathrm{H}, \mathrm{CH}=\mathrm{N}), 12.18$ (s, $1 \mathrm{H}, \mathrm{CONH})$. Mol.form. $\mathrm{C}_{18} \mathrm{H}_{12} \mathrm{Cl}_{3} \mathrm{~N}_{3} \mathrm{O}_{2}$ Calcd. Mol. wt. 409.64.

\section{Results and Discussion}

We have synthesized series of $N^{\prime}$-[(2-chloro-6-methoxyquinolin-3-yl)methylidene]substituted benzohydrazide by a simple and efficient method. The reaction sequence for different synthesized compounds is outlined in Scheme 1. The synthesized compounds $N^{\prime}-$ [(2-chloro-6-methoxyquinolin-3-yl) methylidene]-substituted benzohydrazide (5a-e) were characterized by IR and ${ }^{1} \mathrm{H}$ NMR. The IR spectrum of (5a-e) exhibit absorption band at about $1596-1636 \mathrm{~cm}^{-1}$ due to $-\mathrm{C}=\mathrm{N}$ and amide stretching frequency remain at about 1655-1696 $\mathrm{cm}^{-1}$. ${ }^{1} \mathrm{H}$ NMR of (5a-e) all synthesized compounds exhibits two most important signal, first was singlet for one proton at about $\delta$ values between 11.23 and 12.26 which indicates the $\mathrm{CONH}$ proton and second was the singlet varying from $\delta$ values $8.79-9.11$, which indicates the presence of $\mathrm{CH}=\mathrm{N}$ azomethine group. Aldehyde proton gets converted in to azomethine proton so singlet at $\delta$ value 10.52 due to aldehyde proton was absent in final product .It is the proof for completion of reaction. Reactions were assessed by TLC technique and all these prepared compounds were purified by column chromatography as per requirement and characterized on the basis of spectral studies.

\section{Antimicrobial activity}

The antimicrobial activity was assayed by cup plate agar diffusion method by measuring minimum inhibition zone in $\mathrm{mm}^{14}$. All the synthesized compounds (5a-e) were screened in vitro for antimicrobial activities against bacterial strains such as Escherichia coli, Staphylococcus aureus and Pseudomonas aeruginosa and fungal strains such as Aspergillus Niger, Candida albicans, and penicillium cetrinum at a concentration of $2 \mathrm{mg} / \mathrm{mL}$ in DMSO. Potato dextrose agar and nutrient agar were used as the culture mediums for the antifungal and antibacterial activity, respectively. Chloramphenicol and fluconazole were used as standards for comparison purpose. On the basis of the observed zone of inhibition values, it can be concluded that there is a significant differences in the antibacterial and anti fungal potentials of the compounds. The difference among the responses of different prepared compounds is also significant.

Table 1. Antimicrobial activities for synthesized compounds

\begin{tabular}{ccccccc}
\hline & \multicolumn{6}{c}{ Minimum inhibition zone in mm } \\
\hline \multicolumn{4}{c}{ Antibacterial activity } & \multicolumn{3}{c}{ Antifungal activity } \\
\hline Compd. & \multirow{2}{*}{ E.coli } & $\begin{array}{c}\text { S. } \\
\text { aureus }\end{array}$ & $\begin{array}{c}\text { P. aerug- } \\
\text { inosa }\end{array}$ & $\begin{array}{c}\text { A. } \\
\text { niger }\end{array}$ & $\begin{array}{c}\text { C. } \\
\text { albicans }\end{array}$ & $\begin{array}{c}\text { P. } \\
\text { citrinum }\end{array}$ \\
No. & 09 & 08 & - & 05 & - & - \\
$\mathbf{5 a}$ & 06 & 02 & - & - & - & - \\
$\mathbf{5 b}$ & 09 & 08 & 06 & - & 08 & - \\
$\mathbf{5 c}$ & 12 & 11 & 10 & 08 & 08 & - \\
$\mathbf{5 d}$ & 14 & 11 & 11 & 07 & 07 & - \\
$\mathbf{5 e}$ & 24 & 23 & 22 & NT & NT & NT \\
Chloramphenicol & NT & NT & NT & 25 & 26 & 24 \\
Fluconazole & N & &
\end{tabular}

'-'No sensitivity; NT- Not tested 


\section{Conclusion}

Among the synthesized benzohydrazides with azomethiene group, compounds with $\mathrm{CH}_{3}$, $\mathrm{OCH}_{3}, \mathrm{Cl}, \mathrm{Cl}_{2}$ were found to be active for antibacterial as well as antifungal screening. Compounds like $N^{\prime}$-[(2-chloro-6-methoxyquinolin-3-yl)methylidene]-4-methoxybenzohydrazide 4-chloro- $N^{\prime}$-[(2-chloro-6-methoxyquinolin-3-yl)methylidene] benzohydrazide and 2,4-dichloro$N^{\prime}$-[(2-chloro-6-methoxyquinolin-3-yl) methylidene] benzohydrazide show prominent activities. These compounds show grater antibacterial activity as compare to antifungal activity.

\section{Acknowledgement}

The author would like to express the gratitude to A.C.S. College, Narayangaon and University of Pune for supporting this research work. The author thanks the BCUD University of Pune, Pune for funding this research work.

\section{References}

1 Sriram D, Yogeeswari P and Devakaram R V, Bioorg Med Chem., 2006, 14(9), 3113-3118.

2 Narasimhan B, Vikramjeet J, Rakesh N, Sucheta O and Ruchita O, Bioorg Med Chem Lett., 2007, 17(21), 5836-5845.

3 Duarte C D, Tributino J L M, Lacerda D I, Martins M V, Alexandre-Moreira M S, Dutra F, Bechara E J H, De-Paula F S, Goulart M O F, Ferreira J, Calixto J B, Nunes M P, Bertho A L, Miranda A L P, Barreiro E J and Fraga C A M, Bioorg Med Chem., 2007, 15(6), 2421-2433.

4 Nayyar A, Malde A, Coutinho E and Jain R, Bioorg Med Chem., 2006, 14(21), 7302-7310.

5 Ramamurthy B, Rai S B and Ramakrishnan T, Biosci J., 1985, 9(1-2), 47-52.

6 Kömürcü Ş G, Rollas S, Ülgen M, Gorrod J W and Çevikbaş A, Boll Chim Farm., 1995, 134, 375-379.

7 Ülgen M, Durgun B B, Rollas S and Gorrod J W, Drug Metab Interact., 1997, 13, 285-294.

8 Salgın-Gökşen U, Gökhan-Kelekçi N, Göktaş Ö, Köysal Y, Kılıç E, Işık Ş, Aktay G and Özalp M, Bioorg Med Chem., 2007, 15(17), 5738-5751.

9 Zhang Z H, Drewe J, Tseng B, Kasibhatla S and Cai S X, Bioorg Med Chem., 2004, 12(13), 3649-3655.

10 Sevim Rollas and Güniz Küçükgüzel Ș, Molecules, 2007, 12, 1910-1939.

11 Monazza Serwar, Tashfeen Akhtar, Shahid Hameed and Khalid M Khan, ARKIVOC, 2009, (vii), 210-221.

12 Meth-Cohn O and Narine B, Tetrahedron Lett., 1978, 19(23), 2045-2048.

13 Meth-Cohn O, Narine B and Tarnowski B, J Chem Soc Perkin Trans 1, 1981, 1520.

14 Barry A L, The Anti-microbial Susceptibility Test, Principle and Practice; $2^{\text {nd }}$ Ed., By Illuslea and Febiger: Philadelphia, PA, U S A, 1976; 180. 